\title{
Microbial Chromate Reductases: Novel and Potent Mediators in Chromium Bioremediation-A Review
}

\author{
John Geraldine Sandana Mala ${ }^{1^{*}}$, Satoru Takeuchi ${ }^{2}$, Dhanasingh Sujatha ${ }^{3}$ and Uthirappan Mani ${ }^{3^{*}}$ \\ ${ }^{1}$ C/o Takenen, 10/1046, Pari Road, Mogappair East, Chennai-600037, India \\ ${ }^{2}$ Factory of Takeuchi Nenshi, TAKENEN, 85NE Takamatsu, Kahoku, Ishikawa 929-1215, Japan \\ ${ }^{3}$ Department of Biochemistry and Biotechnology, CSIR-Central Leather Research Institute, Adyar, Chennai-600020, India \\ E-mail: geraldinesm@gmail.com, manitoxicology@gmail.com
}

\begin{abstract}
Heavy metal pollution from the growing industrialization are a significant cause of environmental concern. Chromium (Cr) is commonly used in the production of stainless steel, textile dyeing, electroplating, as nuclear coolants and largely in chrome tanning of hides and skins. About $90 \%$ of leather is produced by chrome tanning and the leather industry contributes to an overload of $\mathrm{Cr}$ toxicity in tannery effluents. Accumulation of $\mathrm{Cr}^{6+}$ is carcinogenic, genotoxic and teratogenic to organisms. Biological methods are 'green' approaches for chromium bioremediation and microorganisms are the desired candidates for pollution abatement. Microbial chromate reduction is mediated by chromate reductases (ChrRs) which may be expressed constitutively or inducibly. ChrRs have been produced by a number of bacteria, fungi and yeasts and may be extracellular or localized in the membrane or cytosol. ChrRs are dependent on electron donors such as reduced Nicotinamide adenine dinucleotide (NADH) or reduced Nicotinamide adenine dinucleotide phosphate (NADPH) or reduced Glutathione (GSH) as cofactors. In chromate reduction by ChrRs, $\mathrm{Cr}^{6+}$ undergo one electron transfer to produce an unstable $\mathrm{Cr}^{5+}$ radical that is converted to stable and less toxic $\mathrm{Cr}^{3+}$. Putative $\mathrm{ChrR}$ genomic sequences have been studied with $99 \%$ sequence similarity in Gram negative bacteria. ChrRs are valuable resources in different environments for chromate reduction. This review is to discuss the expression and characteristics of ChrRs and their mechanisms in reduction of $\mathrm{Cr}^{6+}$ toxicity in order to provide a comprehensive understanding of this novel class of enzymes for promising applications in $\mathrm{Cr}$ bioremediation.
\end{abstract}

Keywords: bioremediation, chromate reductase, chromium, structural properties

\section{Introduction}

Chromium (Cr) is a heavy metal and belongs to Group 6, block-d of the dynamic periodic table and is a transition metal with an atomic number of 24 . Cr is widely used in stainless steel production, manufacture of alloys, textile dyeing, electroplating, as pigments, as industrial catalysts, as nuclear coolants in bioreactors and in tanning of hides and skins ${ }^{[1]}$. Leather industry contributes to an overload of $\mathrm{Cr}$ in tannery effluents causing major environmental concerns. About $90 \%$ of leather goods are chrome tanned. Chrome tanning is preferred to vegetable tanning of hides and skins due to production of soft and pliable leather of good quality with even finishings. India is one of the largest economy in the export of leather and approaches to reduce or eliminate $\mathrm{Cr}$ content is of utmost significance. $\mathrm{Cr}$ toxicity leads to mutagenic, carcinogenic and teratogenic effects upon human consumption ${ }^{[2]}$. Cr is also toxic to plants and animals as well. Cr exists in oxidation states ranging from -2 to +6 , while $\mathrm{Cr}$ is stable only at +3 and +6 oxidation states ${ }^{[3]} \cdot \mathrm{Cr}^{6+}$ is the toxic species and is readily soluble which relates to its toxic effects while $\mathrm{Cr}^{3+}$ is relatively benign, less mobile, insoluble and has toxic effects at very high concentrations forming ternary adducts with DNA causing DNA damage ${ }^{[4]}$. The permissible limits of $\mathrm{Cr}$ in drinking water is $0.05 \mathrm{mg} / \mathrm{L}$ according to the World Health Organization (WHO). Mala et al. (2006) ${ }^{[5]}$ have reported $1.5 \mathrm{~g} / \mathrm{ml} \mathrm{Cr}^{3+}$ and $383.7 \mu \mathrm{g} / \mathrm{ml} \mathrm{Cr}^{6+}$ in spent chrome liquor obtained after chrome tanning process, and $127 \mathrm{mg} / \mathrm{ml} \mathrm{Cr}^{3+}$ and $64.7 \mu \mathrm{g} / \mathrm{ml}$ $\mathrm{Cr}^{6+}$ in the mainstream tannery effluent. During chrome tanning, chrome (basic chromium sulfate, $\mathrm{Cr}^{3+}$ ) is used as $10 \%$ in float in roller drums and $\mathrm{Cr}^{3+}$ is oxidized to $\mathrm{Cr}^{6+}$ and both species are discharged into the effluent. $\mathrm{Cr}^{6+}$ is classified as a priority pollutant and is listed as a Class A human carcinogen by US Environmental Protection Agency (US-EPA).

Copyright (C2020, John Geraldine Sandana Mala, et al.

DOI: https://doi.org/10.37256/amtt.112020222

This is an open-access article distributed under a CC BY license

(Creative Commons Attribution 4.0 International License)

https://creativecommons.org/licenses/by/4.0/ 
Therefore, Cr removal in industrial effluents and, mainly tannery effluents is a serious challenge and necessitates several investigations to combat this pollution problem.

Measures to counteract the $\mathrm{Cr}$ pollution load has been of prime concern and there have been vast developments in the physical, chemical and biological methods to reduce $\mathrm{Cr}^{6+}$ toxicity. $\mathrm{Cr}$ removal has generally been carried out by chemical oxidation/reduction, precipitation, electrochemical treatment, reverse osmosis, evaporation recovery and membrane technologies ${ }^{[4]}$. However, conventional methods find difficulty in the removal of highly soluble metal from wastewater and leachates ${ }^{[6]}$.

Biological methods are 'green' approaches for chromium bioremediation and microorganisms are the desired candidates for pollution abatement. Microbial sources are ecofriendly, less expensive, do not cause sludge formation and are non-toxic. Bacteria, fungi and yeasts have been employed in biosorption, bioaccumulation, chromate reduction, chromate efflux to reduce $\mathrm{Cr}^{6+}$ toxicity ${ }^{[7-10]}$. Mala et al. ${ }^{[5]}$ have used a fungal strain, Aspergillus niger MTCC 2594 for $\mathrm{Cr}$ removal by the fungal viable biomass by bioaccumulation and biosorption of $\mathrm{Cr}$ in spent chrome liquor with about $78 \%$ and $83 \% \mathrm{Cr}$ removal respectively. Chromate reduction is considered to be a viable strategy in combating Cr-associated toxicity due to the formation of the reaction product, $\mathrm{Cr}^{3+}$ which is almost considered to be non-toxic. Bacterial organisms mainly facilitate chromate reduction, while fungal species are good for biosorption ${ }^{[11]}$. The reduction of hexavalent $\mathrm{Cr}$ to trivalent $\mathrm{Cr}$ is a viable process, mediated by $\mathrm{ChrR}$ enzymes under aerobic conditions via its cytosolic form and in anaerobic respiration through its membrane-bound component ${ }^{[12]}$. Sanjay et al. ${ }^{[13]}$ have isolated two bacterial species from tannery effluent, identified as Klebsiella pneumoniae and Mangrovibacter yixingensis which showed the presence of a chromate reducing gene by PCR, which could find potential application in $\mathrm{Cr}$ bioremediation. The toxicity of $\mathrm{Cr}^{6+}$ and accumulation of reduced $\mathrm{Cr}^{3+}$ culminating in the formation of toxic chromium-DNA adducts in the nucleus are shown in Figure1.

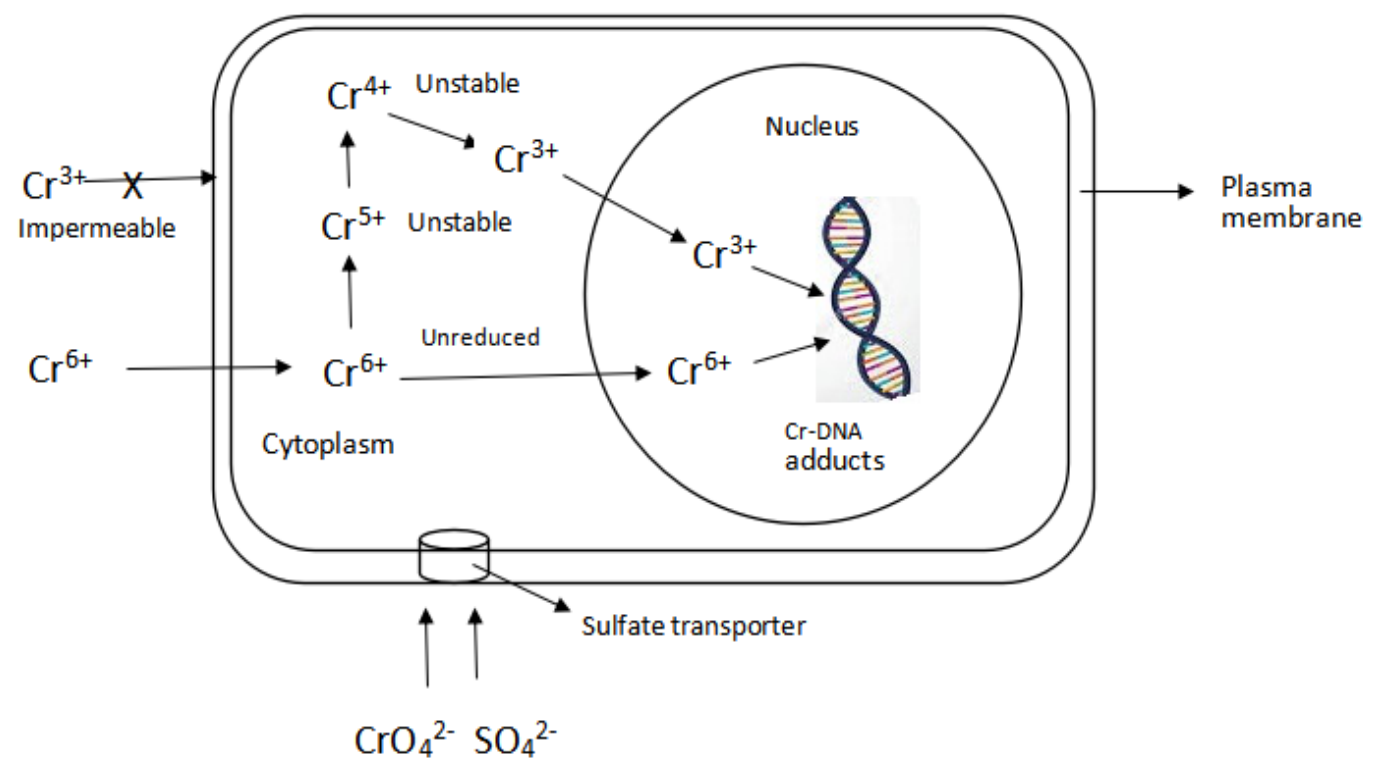

Figure 1. Intracellular chromate accumulation in microorganisms ${ }^{[73]} \cdot \mathrm{Cr}^{6+}$ permeates through the plasma membrane of microorganisms

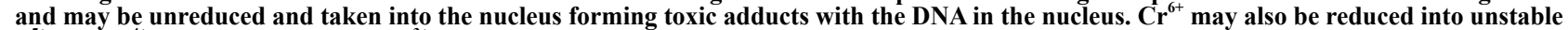
$\mathrm{Cr}^{5+}$ and $\mathrm{Cr}^{4+}$ and stable non-toxic $\mathrm{Cr}^{3+}$ which when accumulates intracellularly permeates into the nucleus forming ternary toxic $\mathrm{DNA}$ adducts.

Chromate ions may also be transported via the sulfate transporter in the plasma membrane as it resembles sulfate ions in structure and accumulate intracellularly

Chromate reductases (ChrRs), found in chromium resistant bacteria are known to catalyse the reduction of $\mathrm{Cr}^{6+}$ to $\mathrm{Cr}^{3+}$ and have recently received particular attention for their potential use in bioremediation process. Different ChrRs such as ChrR, YieF, NfrA, NemA, and Lpd1 (Table 1), have been identified from bacterial sources which are located either in soluble fractions (cytoplasm) or bound to the membrane of the bacterial cell. The reducing conditions under which these enzymes are functional can either be aerobic or anaerobic or sometimes both ${ }^{[19]}$. Sequence homology studies indicated that ChrR activity is probably not the primary function of these enzymes. For example, YieF of Escherichia coli reduces $\mathrm{Cr}(\mathrm{VI})$ and quinone with a broad substrate specificity, whereas, the ChrR of Pseudomonas ambigua reduces nitrate which was absent in ChrR of P. putida. ${ }^{[20]}$. However, ChrRs are the mainly responsible enzymes in the reduction of chromate to insoluble and non-toxic $\mathrm{Cr}^{3+}$ in microorganisms. 
Table 1. Some Microbial enzyme homologues with chromate-reducing activity

\begin{tabular}{cccc}
\hline ChrR enzyme homologues & Microorganism & Enzyme Type & Reference \\
\hline YieF & E.coli & Chromate reductase & {$[14]$} \\
NemA & E. coli & Chromate reductase & {$[15]$} \\
Frm2 & Wickerhamomyces anomalus M10 & Type II Nitroreductases & {$[16]$} \\
Ycp4 & Wickerhamomyces anomalus M10 & Flavoprotein wrbA & {$[16]$} \\
Yah1 & Cyberlindnera jadinii M9 & Mitochondrial Ferredoxine-NADP reductase & {$[16]$} \\
Lpd1 & Cyberlindnera jadinii M9 & Membrane FAD flavoprotein & {$[16]$} \\
NfrA & B.subtilis & Chromate reductase & {$[18]$} \\
ChrR & B.methylotrophicus & Chromate reductase & {$[14]$} \\
NfsA & E.coli & Chromate reductase & \\
\hline
\end{tabular}

The present review highlights the production of ChrRs from different microbial sources intracellularly or extracellularly or membrane-bound; the expression patterns of ChrRs; structural and genomic features of the enzyme and the potential mechanisms of enzyme-mediated chromate reduction both by aerobic and anaerobic pathways with production of intermediate unstable $\mathrm{Cr}$ species proceeding to insoluble non-toxic $\mathrm{Cr}^{3+}$ species. Finally, the applications of the chromate reducing enzyme, ChrR, in the bioremediation of $\mathrm{Cr}$ contaminated industrial wastewaters and soils is discussed. The aim of this review is to provide a comprehensive understanding of microbial ChrR enzymes which can play a significant role in the restoration of Cr-containing environments. This review draws particular attention in the context of the localization of the enzyme and its expression with their characteristics suitable for $\mathrm{Cr}$ bioremediation and the aerobic and anaerobic mechanisms of chromate reduction.

\section{ChrRs from microbial sources}

Among bacteria, Bacillus megatarium TKW3 ${ }^{[21]}$; Bacillus sp. ${ }^{[22]}$; Bacillus sp. strain KSUCr5 ${ }^{[23]}$; B. subtilis ${ }^{[24]}$; B.circulans ${ }^{[25]}$; B.cereus ${ }^{[26]}$; B.subtilis ${ }^{[17]}$; B.methylotrophicus ${ }^{[18]}$; Bacillus sp. SFC 500-1E ${ }^{[27]}$; Bacillus sp. M6 ${ }^{[28]}$ have been extensively studied for $\mathrm{Cr}$ bioremediation. Ackerley et al. ${ }^{[20]}$ have identified NADH, NADPH, flavoproteins and other heme proteins that readily reduce $\mathrm{Cr}^{6+}$ to $\mathrm{Cr}^{3+}$ in addition to reductases existing inside the bacterial cells. The reducing component is a soluble reductase produced constitutively or sometimes both constitutively and inducibly, and is a highly regulated system ${ }^{[29]}$. Recently, Ma et al. ${ }^{[30]}$ have reported a mixed bacterial consortium for enzyme-mediated chromate reduction.

Mala et al. ${ }^{[18]}$ have reported a new B.methylotrophicus strain isolated from tannery sludge as an efficient candidate for chromate reduction. ChrR activity was obtained in a low-cost defined medium formulation and the extracellular enzyme was inducible at $12 \mathrm{~h}$ substrate addition. Reduced glutathione was required as electron donor for enhanced specific activity. Rath et al. ${ }^{[31]}$ have reported high titres of ChrR production by a B.amyloliquefaciens CSB 9 strain isolated from a chromite mine environment. ChrR was extracellular and the production was enhanced by optimization of complex culture medium at $16 \mathrm{~h}$ when compared to production of the enzyme in unoptimized culture medium at $20 \mathrm{~h}$. ChrR enzyme was extracellular and inducible by Arthrobacter SUK 1201 isolated from chromite mine and exhibited high affinity to $\mathrm{Cr}^{6+}$ ${ }^{[32]}$. A P.aeruginosa bacterial strain isolated from tannery effluent tolerated up to $500 \mathrm{ppb}$ chromium concentration and produced an extracellular $\mathrm{ChrR}$ with thermostability at $50^{\circ} \mathrm{C}{ }^{[33]}$.

Fungi and yeast species are also valuable sources for production of ChrR enzymes ${ }^{[34-36]}$. A filamentous fungus, Penicillium sp. isolated from polluted air with industrial vapors produced an intracellular hexavalent ChrR with highest activities at $\mathrm{pH} 7.0$ and at $37^{\circ} \mathrm{C}$ and required NADH as electron donor for reduction potential ${ }^{[37]}$. A ChrR from Aspergillus niger was mainly intracellular in the soluble fraction. Intracellular accumulation of $\mathrm{Cr}^{3+}$ revealed $\mathrm{Cr}^{6+}$ removal by chromate reduction process and the fungal mycelia showed the presence of both $\mathrm{Cr}^{6+}$ and $\mathrm{Cr}^{3+}$ species ${ }^{[38]}$.

Thus, ChrRs are ubiquitous enzymes produced by a variety of microorganisms (Table 2) with varying productivities and characteristics and are responsible for toxic $\mathrm{Cr}^{6+}$ reduction to non-toxic $\mathrm{Cr}^{3+}$ and therefore are promising candidates for chromium bioremediation particularly in industrial wastewaters. 
Table 2. Microbial sources of ChrR enzyme production

\begin{tabular}{|c|c|c|c|c|}
\hline Microorganism & Isolation habitat & $\mathrm{Cr}^{6+}$ reduction (\%) & ChrR activity & Reference \\
\hline Microcosm & Chromate polluted industrial site groundwater & 99.47 & ND & [39] \\
\hline E.coli & Heavily polluted soil & ND & $361.33 \mathrm{U} / \mathrm{mg}$ protein & {$[40]$} \\
\hline B.methylotrophicus & Tannery sludge & 91.38 & $312.99 \mathrm{U} / \mathrm{mg}$ protein & [18] \\
\hline B.amyloliquefaciens CSB 9 & Chromite mine & ND & $3.67 \mathrm{U} / \mathrm{ml}$ & {$[31]$} \\
\hline Arthrobacter sp. SUK 1201 & Chromite mine & ND & $5.803 \mathrm{U} / \mathrm{mg}$ protein & {$[32]$} \\
\hline P.aeruginosa & Tannery effluent & $500 *$ & $0.056 \mathrm{U} / \mathrm{mg}$ protein & {$[33]$} \\
\hline Penicillium sp. & Polluted air with industrial vapors & 70.0 & $94.07 \mathrm{U} / \mathrm{mg}$ protein & [37] \\
\hline Pseudomonas sp. G1DM21 & Cr contaminated industrial landfill & 93.06 & $0.52 \mathrm{U} / \mathrm{mg}$ protein & [41] \\
\hline Stenotrophomonas maltophilia & Automobile part chrome plating effluent & 92.0 & ND & {$[42]$} \\
\hline Trichoderma pseudokoningii & Tannery effluent & ND & $1.03 \mathrm{U} / \mathrm{mg}$ protein & {$[35]$} \\
\hline
\end{tabular}

*ppb; ND-Not Determined in the References

\section{Localization of ChrRs}

ChrRs may be produced extracellularly ${ }^{[18,30,33]}$, in the cell-free extract i.e., the soluble fraction ${ }^{[34,38,42]}$ or membranebound ${ }^{[24]}$. Low yields of ChrR may be present in the whole cells ${ }^{[18,43]}$. Wani et al. ${ }^{[44]}$ have reported that ChrRs may be extracellular, intracellular or membrane-bound. Many bacteria produce ChrRs in the intracellular fraction while few bacterial isolates produce the enzyme in the extracellular supernatant. Nine species of bacterial isolates produced ChrR enzymes both in intracellular and extracellular fractions ${ }^{[45]}$. Recent literature have demonstrated cell envelop as the localization site of ChrRs. A newly isolated chromium reducing bacterium, Oceanobacillus oncorhynchi W4 produced ChrR with a removal rate of $82.9 \%$ and the cell envelop was found to be the main location of the reductase enzyme ${ }^{[46]}$. Li et al. ${ }^{[28]}$ have reported chromate reduction by a Bacillus sp. M6 in the cell envelop as well as the cytoplasm and the reduced $\mathrm{Cr}^{3+}$ precipitates were distributed both on the surface of the cells and in the cytoplasm.

Hexavalent chromate reduction by Aspergillus niger led to formation of $\mathrm{Cr}^{3+}$ inside the fungal cells and on the mycelial surface by ChrR which was produced only intracellularly by assays of the enzyme activities in permeabilized cells, cell-free extracts and cell debris ${ }^{[38]}$. Ontanon et al. ${ }^{[27]}$ have studied that chromate reduction was mediated by a reductase enzyme (ChrR) in the soluble fraction of Bacillus sp. SFC 500-IE. Studies of chromate reduction in a mixed bacterial consortium revealed that extracellular fraction was the main site for the enzyme-mediated reduction ${ }^{[30]}$. The localization of microbial ChrRs in the cell fraction is given in Table 3.

Table 3. Localization of microbial ChrR enzymes

\begin{tabular}{ccc}
\hline Microorganism & Cell fraction & Reference \\
\hline P.aeruginosa & Extracellular & {$[30]$} \\
B.methylotrophicus & Extracellular & {$[18]$} \\
Mixed bacterial consortium & Extracellular & {$[30]$} \\
Bacillus sp. SFC 500-IE & Intracellular & {$[27]$} \\
Aspergillus niger & Intracellular & {$[38]$} \\
Stenotrophomonas maltophilia & Intracellular & {$[42]$} \\
B.subtilis & Membrane-bound & {$[24]$} \\
B.methylotrophicus & Whole cell & {$[18]$} \\
Oceanobacillus oncorhynchi W4 & Cell envelop & {$[46]$} \\
Bacillus sp. M6 & Cell envelop and cytoplasm & {$[28]$} \\
\hline
\end{tabular}

\section{Expression of ChrRs}

ChrRs may be constitutive ${ }^{[6,24]}$ or inducibly expressed ${ }^{[18,43]}$. ChrR activity of Rhodobacter sphaeroides was observed whether chromate ions were present or not and was therefore constitutively expressed ${ }^{[6]}$. Constitutive enzymes are those which can be expressed inside the cells or secreted into the culture medium whether their substrates are present or absent. Several metabolic enzymes are constitutively expressed for the need of their survival by performing vital metabolic activities. In contrast, inducibly expressed enzymes are those which are secreted in the presence of a substrate or inducer. This kind of inducible enzyme expression occur in particular habitats where the microorganisms have to encounter stressful adaptation by expression of the enzymes responsible for tolerance to the stress condition. This is particularly the case where microorganisms are isolated from chromite mine environments or industrial effluents or tannery by-products. 
In our earlier study of chromate tolerance by a B.methylotrophicus isolated from tannery effluents, the ChrR enzyme was inducibly expressed when the substrate, $\mathrm{K}_{2} \mathrm{Cr}_{2} \mathrm{O}_{7}$ was added at $12 \mathrm{~h}$ after inoculation of the bacterial preinoculum in the culture medium ${ }^{[18]}$; while in the case of a Streptomyces sp. MC1, ChrR was inducibly expressed at $24 \mathrm{~h}$ substrate addition

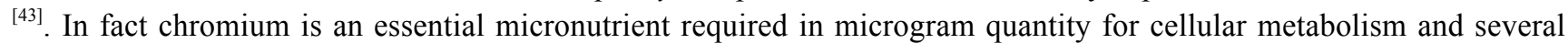
microorganisms express the ChrR constitutively, also to tolerate excess levels, while ChrRs which are inducibly expressed also express the enzyme constitutively in lower levels. Table 4 provides the expression system of various microbial ChrRs. Thereby, the expression of ChrR is dependent not only on the microorganisms, but also the source of environment or habitat from where the microorganisms are isolated. Irazusta et al. ${ }^{[16]}$ have isolated about four yeast species from textile dye industry effluents which show reductase activities for applications in chromium bioremediation. A Bacillus sp. SFC 500-1E has been isolated from a bacterial consortium SFC 500-1 which was obtained from tannery sediments and displayed tolerance to $\mathrm{Cr}^{[27]}$.

Table 4. Expression system of microbial ChrRs in th presence (+) or absence (-) of chromate

\begin{tabular}{cccc}
\hline Microorganism & Expression system & Chromate source & Reference \\
\hline Rhodobacter sphaeroides & Constitutive & $+/-$ & {$[6]$} \\
B.subtilis & Constitutive & + & {$[24]$} \\
B.methylotrophicus & Inducible at $12 \mathrm{~h}$ & + & {$[18]$} \\
Streptomyces sp. $M C 1$ & Inducible at $24 \mathrm{~h}$ & + & {$[43]$} \\
\hline
\end{tabular}

\section{Structural and genomic features of ChrRs}

Chromate reductases have received recent attention and very few reports exist on their purification and characteristics of the purified enzymes. Generally, crude extracts of ChrRs have been characterized for their biochemical and physiochemical properties ${ }^{[18,42]}$. This is because their potential applications for bioremediation of contaminated environments require cost-effective procedures and purification to homogeneity is avoided. However, in academic research, it is quite important to understand the structure and structural and biochemical properties of purified ChrRs and evaluation of their kinetics for better elucidations of their molecular mechanisms in order to reduce toxic $\mathrm{Cr}^{6+}$ intracellularly or extracellularly or in the membrane fraction, accomplished by a variety of spectroscopic and microscopic techniques (Table 5). ChrRs are ubiquitously expressed by microorganisms either constitutively or more often inducibly depending upon their habitat and presence of an inducer i.e. a stress factor such as $\mathrm{Cr}$ metal ions to tolerate the stress load and to perform their metabolic activities.

Table 5. Structural and genomic features of microbial ChrRs

\begin{tabular}{|c|c|c|c|c|c|}
\hline \multirow{4}{*}{ Structural features } & Microorganism & Purification strategy & Molecular weight & Cofactor & Reference \\
\hline & Stenotrophomonas maltophilia & Crude extract & $\begin{array}{c}25 \mathrm{kDa} \\
(\mathrm{SDS}-\mathrm{PAGE}) \\
\end{array}$ & - & {$[42]$} \\
\hline & $\begin{array}{c}\text { Thermus scotoductus } \\
\text { SA-01 }\end{array}$ & $\begin{array}{c}\text { Fractionation, Ion- } \\
\text { exchange chromatography, } \\
\text { hydrophobic interaction } \\
\text { chromatography, dye affinity } \\
\text { chromatography, size } \\
\text { exclusion chromatography }\end{array}$ & $72.4 \mathrm{kDa}$ & FMN & {$[47]$} \\
\hline & E.coli & $\begin{array}{l}\text { His-tagged Ni metal ion } \\
\text { affinity chromatography }\end{array}$ & $80 \mathrm{kDa}$ & FMN & {$[48]$} \\
\hline \multirow{4}{*}{ Genomic features } & Microorganism & ChrR gene size & \multicolumn{3}{|c|}{ Reference } \\
\hline & $\begin{array}{c}\text { Thermoanaerobacter } \\
\text { thermohydrosulfuricus BSB-33 }\end{array}$ & $2597606 \mathrm{bp}$ & \multicolumn{3}{|c|}{$[53]$} \\
\hline & Thermus scotoductus SA-01 & 1050 bp ORF & \multicolumn{3}{|c|}{$[47]$} \\
\hline & S.maltophilia & 468 bp $C h r \mathrm{R}$ fragment & \multicolumn{3}{|c|}{$[42]$} \\
\hline
\end{tabular}

Hexavalent $\mathrm{Cr}$ reduction was evaluated in crude cell-free extracts of Stenotrophomonas maltophilia and a protein of molecular weight about $25 \mathrm{kDa}$ was obtained in an SDS-PAGE gel with its band intensity corresponding to the concentrations of $\mathrm{Cr}^{6+}$ in the culture medium ${ }^{[42]}$. The protein band could be the reductase enzyme that was responsible for chromate reduction, which was confirmed to be ChrR by in-silico studies. Opperman et al. ${ }^{[47]}$ have identified a novel ChrR from Thermus scotoductus SA-01 and have purified the enzyme to homogeneity. The purification strategy involved 5 steps: fractionation, Ion-exchange chromatography with DEAE-Toyopearl $650 \mathrm{M}$ column; hydrophobic interaction chromatography with phenyl-Toyopearl $650 \mathrm{M}$ column; dye affinity chromatography with Blue Sepharose CL-6B column 
and size-exclusion chromatography on a Sephacryl S-100 HR column. The overall purification was 450 -fold with a yield of $9.1 \%$. The purified enzyme was a homodimeric protein and contained a Flavin mononucleotide cofactor bound non-covalently and the molecular mass of each monomer subunit was approximately $36 \mathrm{kDa}$. The native protein was found to have a molecular weight of $72.4 \mathrm{kDa}$ by size-exclusion chromatography. Thereby, these studies established the homodimeric quaternary structure of the purified ChrR. The cofactor was identified as Flavin Mononucleotide (FMN) by Thin-layer chromatography.

The crystal structure of ChrR from Gluconacetobacter hansenii was determined at $2.25 \AA$ resolution by Jin et al. ${ }^{[48]}$. This enzyme was revealed to be a homotetramer with a single bound FMN per subunit. A residue S118A participated in the coordination of FMN in the active site. A number of side chains were involved in the positioning of FMN in the active site. A metal anion binding site and the enzyme cofactors and their proximity relationships were identified to be involved in chromate reduction by site-directed substitution studies.

ChrR isolated from E.coli renamed from $\mathrm{YieF}^{[14]}$ is an $80 \mathrm{kDa}$ homotetramer comprising of four 20-22 $\mathrm{kDa}$ subunits with an FMN cofactor attached to each monomer ${ }^{[48]}$. Two monomeric subunits form a $50 \mathrm{kDa}$ dimer while other two monomeric units together constitute the $80 \mathrm{kDa}$ tetramer. Thus the molecular architecture of the homotetramer is asymmetrical ${ }^{[49]}$. This result reflects that in an SDS-PAGE, the bands obtained could be four when all of the subunits were obtained as monomers or could be dimers when the two asymmetrical monomers are cleaved. Each of the monomer is composed of five parallel $\beta$-sheets to form a sheet of secondary structure, with two $\alpha$-helices on either sides of the $\beta$-sheet structure. FMN is present at the C-terminal of the $\beta$-sheet surrounded by three loop structures. In the loop structures, hydrogen bonds (H-bonds) are formed by $\mathrm{G}^{13} \mathrm{SLRKGSFN}^{21}$ and $\mathrm{P}^{88} \mathrm{EYNY}^{86}$. Two monomeric subunits bind with each of their C-terminal regions of the $\beta$-sheet in an anti-parallel direction forming a dimeric structure. The formation of tetramer occurs with two H-bonds between $\mathrm{Tyr}^{137}$ and Glu ${ }^{155}$ of one dimer and $\mathrm{Arg}^{133}$ and $\mathrm{Tyr}^{93}$ of the other dimer ${ }^{[50]}$. FMN cofactor is bound to the bottom of a pocket formed by loop structures and the conserved amino acids at the top of the pocket are $\mathrm{Glu}^{83}, \mathrm{Tyr}^{84}$ and $\mathrm{Arg}^{109}$ providing binding sites for NAD(P)H and chromate ${ }^{[51,52]}$.

Genomic studies of ChrRs have been studied in bacteria as well as yeast species. Bhattacharya et al. ${ }^{[53]}$ have studied the complete genome sequence of chromate-reducing Thermoanaerobacter thermohydrosulfuricus BSB-33, a first report of $\mathrm{Cr}^{6+}$ reducing strain. The sequenced genome of T.thermohydrosulfuricus BSB-33 comprised 2597606 bp and encoded 2581 protein genes, 12 rRNA and 193 pseudogenes. The GC content of the genome was $34.2 \%$. The phylogenetic tree was constructed and analysed by the maximum likelihood method using MEGA v.5.1.

The ChrR of Thermus scotoductus SA-01 was found to be encoded by an open reading frame (ORF) of $1050 \mathrm{bp}$ and encoding a single protein of $38 \mathrm{kDa}$ of $\mathrm{ChrR}$ which was related to the old yellow enzyme family of xenobiotic reductases primarily involved in oxidative stress response, by sequence analysis ${ }^{[47]}$.

\section{Genetic manipulations of microbial ChrRs}

In order to obtain maximal or optimal enzyme activities it is a common lab procedure to perform cloning of the enzyme and investigate its productivity and characteristics. Likewise, chromate reducing genes have also been cloned for amplification in suitable vectors by direct or other PCR techniques and studied for overexpression and annotations of their gene sequences and phylogenetic analysis. Bhattacharya et al. ${ }^{[53]}$ have first reported the complete genome sequence of ChrR in an anaerobic bacterium, Thermoanaerobacter thermohydrosulfuricus BSB-33 and have elucidated its genetic elements that mediate chromate reduction. The complete genome was annotated as part of the Oak Ridge National Laboratory genome annotation pipeline followed by manual curation using GenePRIMP gene predicting software. The databases employed for analysing the curated sequence information were the National Center for Biotechnology Information (NCBI) nonredundant database, UniProt, TIGRFam, Pfam, PRIAM, KEGG, COG and InterPro. The genomic information were used to provide an insight of the ability of the $T$. thermohydrosulfuricus to reduce $\mathrm{Cr}^{6+}$. Interestingly, while Thermoanaerobacter sp. have been reported to reduce $\mathrm{Fe}^{3+}$, this BSB-33 strain exhibited $\mathrm{Fe}^{3+}$ as well as $\mathrm{Cr}^{6+}$ reductase activities. This tendency of the strain suggested dissimilarity in genotype.

A genetically engineered chromate reducing bacterial strain of Serratia sp. S2 as ChrT-engineered strain has been created earlier at the laboratory of Zhou and coworkers ${ }^{[54]}$. This engineered strain has been demonstrated to reduce chromate to $40 \%$ at $48 \mathrm{~h}$ of growth. The engineered ChrT strain produced a soluble enzyme that was localized in the cytoplasm and the chromate reducing enzyme required NADH as the electron donor ${ }^{[54]}$.

Deng et al. ${ }^{[55]}$ have cloned the full-length ChrT DNA from Serratia sp. CQMUS2 by direct PCR and obtaining the flanking sequences of ChrT gene by high-efficiency TAIL-PCR. The PCR-amplified ChrT gene was cloned in E.coli. The ChrT gene was found to be an ORF of 567 bp encoding an 188amino acid enzyme. 
Gram positive Arthrobacter aurescens strain MM10, Bacillus atrophaeus strain MM20 and Rhodococcus erythropolis strain MM30 genomic DNA were extracted and subjected to PCR amplification. Partial ChrR gene sequences obtained exhibited $>99 \%$ sequence similarity to Gram negative ChrR gene sequences as those of E.coli and Shigella sp. by wholegenome studies ${ }^{[56]}$. The ChrR gene ChrR of S.maltophilia revealed a fragment of 468 bp by in-silico analysis ${ }^{[42]}$.

\section{Mechanisms of chromate reduction by chromate reductases}

The mechanisms by which hexavalent $\mathrm{Cr}$ is reduced to the nontoxic trivalent $\mathrm{Cr}$ is of renewed interests. It has been understood that $\mathrm{Cr}(\mathrm{VI})$ is transported into the cells where intracellular reduction takes place ${ }^{[57]}$. In a recent study, Wani et al. ${ }^{[44]}$ have described that production of ChrRs from microorganisms are capable of detoxification of $\mathrm{Cr}^{6+}$ by chromate reduction as well as antioxidant defense mechanisms thereby, exhibiting potentials to remediate the metal contaminated environments. Zou et al. ${ }^{[49]}$ have described the chromate reduction process to be mediated by a four electron transfer by ChrR. NAD $(\mathrm{P}) \mathrm{H}$ reduces the FMNs; each FMN, providing one electron during chromate reduction. Three electrons are transferred to chromate while, one electron is transferred to oxygen to produce $\mathrm{H}_{2} \mathrm{O}_{2}$. Because of efficient chromate reduction by ChrR, the bacterium also reduces Reactive oxygen species (ROS) production and is able to show increased resistance to chromate as well as $\mathrm{H}_{2} \mathrm{O}_{2}{ }^{[58]}$.

In 1992, Suzuki et al. ${ }^{[59]}$ have identified a two-step chromate reduction process whereby an intermediate $\mathrm{Cr}^{5+}$ as a result of three equivalents NADH $(3 \mathrm{~mol})$ molecule for every 1 equivalent $\mathrm{Cr}^{6+}(1 \mathrm{~mol})$ by $\mathrm{ChrR}$-mediated chromate reduction. These results were obtained by Electron spin resonance (ESR) spectroscopy with a g-value for $\mathrm{Cr}^{5+}$ equal to 1.979. This result was preceded by a report of Rao et al. ${ }^{[60]}$ who showed the formation of a $\mathrm{Cr}^{5+}$ intermediate by timedependent Electron paramagnetic resonance (EPR) spectroscopy which appeared as a distinct peak from 4 min of reaction until 24 min of reaction while at $30 \mathrm{~min}$, no peak was observed due to completion of chromate reduction of $\mathrm{Cr}^{6+}$ to $\mathrm{Cr}^{3+}$. No $\mathrm{Cr}^{5+}$ was remaining in the reaction mix at $30 \mathrm{~min}$. Formation of $\mathrm{Cr}^{3+}$ was observed from 8 min to 30 min reaction time. A membrane-bound ChrR was constitutively expressed by an alkaliphilic Gram-positive Bacillus subtilis which was able to reduce $100 \%$ of $\mathrm{Cr}^{6+}$ of an initial concentration of $10 \mathrm{mg} / \mathrm{L}$. The formation of $\mathrm{Cr}$ species was observed by SEM/EDX spectrum followed by the identification of the peak as $\mathrm{Cr}^{3+}$ by X-ray photoelectron spectroscopy (XPS). Characteristic bacterial signatures of the Bacillus sp. was observed by FT-IR spectroscopy which revealed that phosphate groups participated in chromate reduction and further, there was a marked reduction in the protein/lipid ratio indicating that proteins were involved in chromate reduction ${ }^{[24]}$. Polti et al. ${ }^{[43]}$ have first identified an enzyme-mediated chromate reduction in Streptomyces sp. MC1 which produced a neutral ChrR localized in the intracellular fraction and the membrane fraction by constitutive expression and this $\mathrm{ChrR}$ was related to $\mathrm{FMN}$ oxidoreductases leading to $\mathrm{Cr}^{6+}$ reduction and provided resistance to chromate.

A ChrR produced by a Proteus sp. isolated from wastewater was subjected to FT-IR spectroscopy to evaluate the cell-metal ion interactions. It was observed that hydroxyl groups on the cell surface were involved in direct $\mathrm{Cr}$ reduction. Phosphate moieties or carbonyl functional groups were also essential for interactions with Cr. Further, ChrR activity resulted in a 10-fold reduction of the $\mathrm{Cr}$ supplemented with the culture growth medium ${ }^{[61]}$.

A ChrR mainly located in the soluble fraction of Aspergillus niger strain was involved in $\mathrm{Cr}^{6+}$ removal by reduction followed by surface immobilization and intracellular accumulation of $\mathrm{Cr}^{3+}$. By their studies using various techniques, SEM and Raman spectra showed presence of $\mathrm{Cr}^{6+}$ and $\mathrm{Cr}^{3+}$ on the mycelia and FT-IR spectroscopy showed that the carboxyl, hydroxide, amine, amide, cyano- and phosphate groups on the fungal cell wall were involved in $\mathrm{Cr}$ binding due to complexation ${ }^{[38]}$. A P.brenneri bacterial strain isolated from coalmine wastewater accumulated metal ions in its exponential growth phase both on the cell surface and within the cell. This showed the growth-related metal accumulation of the bacterial strain ${ }^{[62]}$. Growth-dependent $\mathrm{Cr}^{6+}$ reduction was also observed in Geobacter sulfurreducens ${ }^{[63]}$. Ontanon et al. ${ }^{[27]}$ have suggested the chromate reduction through cytosolic NADH-dependent ChrR in a Bacillus sp. SFC 500-1E as the main mechanism for bioremediation of $\mathrm{Cr}^{6+}$. Tolerance to chromate was also found to be attributed to a chrA gene by $\mathrm{Cr}^{6+}$ extrusion in the bacterial species. In a B.subtilis strain, Zheng et al. ${ }^{[17]}$ have demonstrated the ability of an $n f r$ A gene towards chromate reduction. Focardi et al. ${ }^{[64]}$ have also discussed the one-electron shuttle by ChrR followed by a twoelectron transfer to $\mathrm{Cr}^{6+}$ with formation of $\mathrm{Cr}^{5+}$ and $\mathrm{Cr}^{4+}$ intermediate species. A study of $\mathrm{ChrR}$ of 9 dichromate resistant bacteria showed that the enzyme production was dependent on the time of incubation of the culture with $100 \%$ chromate reduction of most cultures at $96 \mathrm{~h}$ time period ${ }^{[45]}$.

ChrRs are not specific to chromate and possess multiple activities with their substrates ranging from organic compounds to inorganic metal ions. For example, P.brenneri showed tolerance to bimetallic solutions and thus is capable of bioremediation of metal-contaminated effluents ${ }^{[62]}$. Probable mechanisms of chromate reduction in microorganisms by 
Aerobic and Anaerobic pathways are discussed below and illustrated in Figure 2.

Microorganisms can utilize $\mathrm{Cr}^{6+}$ by aerobic ${ }^{[65]}$ or anaerobic ${ }^{[66]}$ or both aerobic and anaerobic ${ }^{[67]}$ pathways to mediate enzymatic chromate reduction to $\mathrm{Cr}^{3+}$. Laxman and More ${ }^{[68]}$ have reported that microorganisms prefer aerobic mechanism of chromate reduction than anaerobic mechanisms. In an earlier study by Germain and Patterson ${ }^{[69]}$, they have suggested that bacteria cannot perform their chromate reduction activity by both aerobic as well as anaerobic mechanisms; while several authors have suggested that microorganisms can accomplish chromate reduction in both aerobic and anaerobic conditions ${ }^{[19,67,70-71]}$. Culture conditions also affect the microbial mechanisms of chromate reduction. P. fluorescens LB300 can reduce $\mathrm{Cr}^{6+}$ both aerobically and anaerobically in solid agar media but not in liquid culture. In medium containing agar with glucose supplementation, the bacteria was capable of aerobic reduction, while anaerobic mechanism of reduction occurred in the presence of acetate as electron donor ${ }^{[72]}$. Under alkaline conditions, Pannonibacter phragmitetus has strong aerobic and anaerobic potentials to undergo chromate reduction ${ }^{[67]}$.

Thereby, microorganisms can reduce chromate depending upon several factors in their environment and during their growth in culture media. However, most microorganisms preferably reduce chromate by aerobic mechanisms, and yet, a lot of studies are required for investigations of their mechanisms of chromate reduction ${ }^{[68]}$.

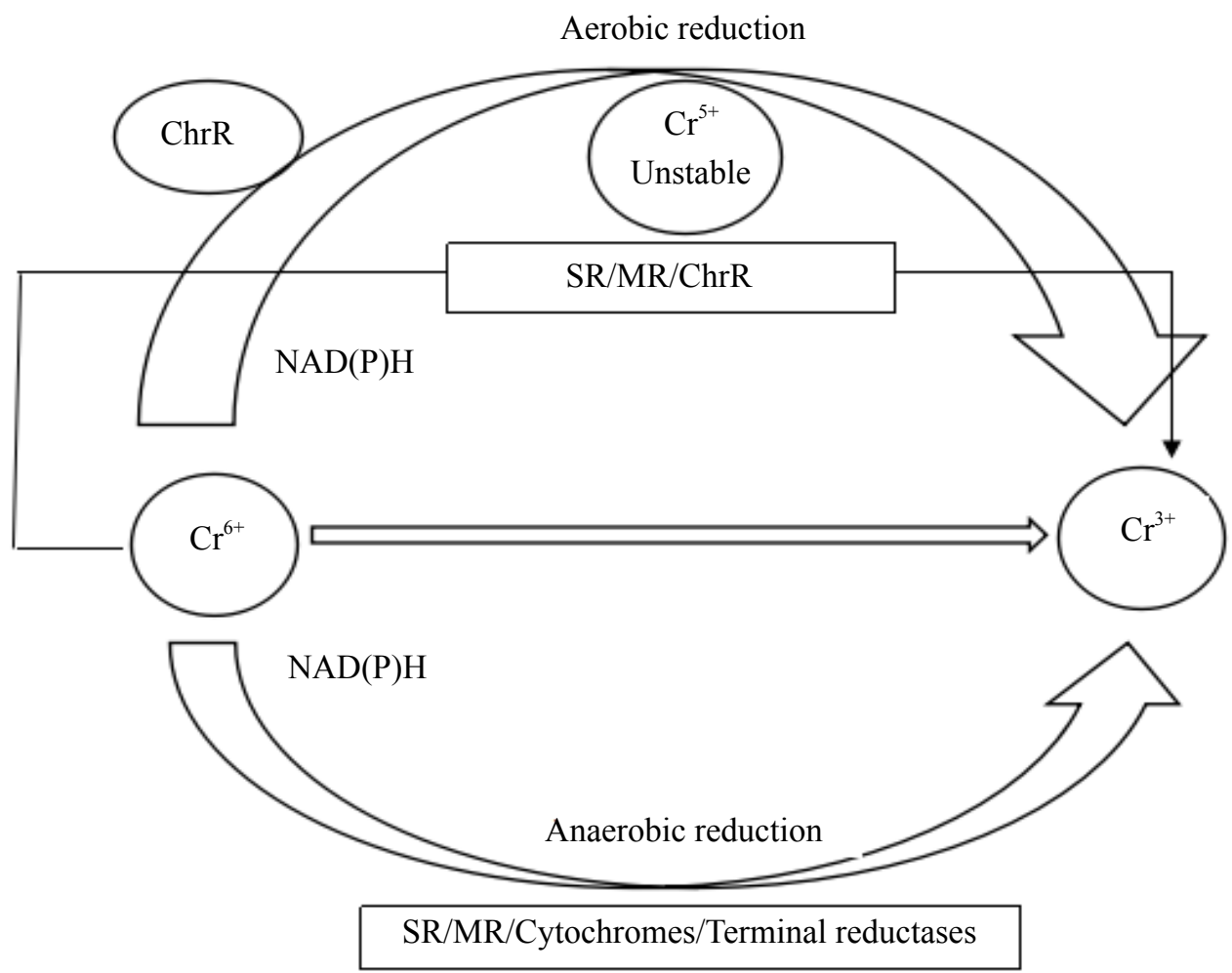

Figure 2. Aerobic and Anaerobic pathways of microbial chromate reduction ${ }^{[73]}$. Aerobic and Anaerobic chromate reduction is mediated by soluble ChrR or cytochrome and terminal reductase in the presence of NADH/NADPH via electron transfer. SR-Soluble reductases; MRMembrane-bound reductases; ChrRs-Chromate reductases

\section{Aerobic chromate reduction}

Chromate reduction in aerobic bacteria is carried out by cellular reductants such as glutathione and NAD(P) $\mathrm{H}$-dependant $\mathrm{ChrRs}{ }^{[65]}$. Aerobic chromate reduction occurs in a three electron transfer from $\mathrm{Cr}^{6+}$ to produce $\mathrm{Cr}^{3+}$. One electron transfer from $\mathrm{Cr}^{6+}$ yields $\mathrm{Cr}^{5+}$ which is an unstable intermediate which immediately leads to formation of $\mathrm{Cr}^{3+}$ by a two electron transfer from $\mathrm{Cr}^{5+}$ mediated by NADH or NADPH or electron from the endogenous reserves ${ }^{[73]}$. The E.coli ChrR enzyme, YieF, recently named ChrR, involves a four-electron transfer, where, three electrons are required for direct formation of $\mathrm{Cr}^{3+}$ and another electron is required to be transferred to oxygen ${ }^{[29]}$. Aerobic chromate reduction is associated with soluble proteins localized in the cytosol ${ }^{[74]}$ and require $\mathrm{NAD}(\mathrm{P}) \mathrm{H}$ as electron donor ${ }^{[71]}$. This kind of aerobic reduction could be employed for detoxification of $\mathrm{Cr}$-contaminated environment ${ }^{[75]}$. The soluble reductase reduces $\mathrm{Cr}^{6+}$ to $\mathrm{Cr}^{3+}$ which can bind to electronegatively charged functional groups on the bacterial cell surface to favor precipitation or undergo complexation with cell envelope exopolymers that can prevent heavy metal accumulation in the cytoplasm, thereby, 
leading to detoxification of $\mathrm{Cr}^{\left[{ }^{[76]}\right.}$. Several microorganisms are capable of aerobic chromate reduction such as E.coli, B.subtilis, P.aeruginosa, A.eutrophus, Shewanella alga and Ochrobactrum and Paracoccus sp. ${ }^{\text {[75] }}$.

\section{Anaerobic chromate reduction}

Anaerobic chromate reduction in microorganisms utilize chromate as the terminal electron acceptor and is mediated by membrane-bound reductases, cytochromes and hydrogenases in the electron transport system. Anaerobic reduction was first reported in P.dechromaticans in 1975 by Romaneko and Korenkov ${ }^{[77]}$. Anaerobic chromate reduction can occur in the periplasmic space by membrane-bound hydrogenase or reduced cytochrome ${ }^{[73]}$. The mechanism of anaerobic chromate reduction in the presence of glucose as electron donor occurs with chromate as terminal electron acceptor ${ }^{[78]}$. Some microorganisms capable of anaerobic chromate reduction are Enterobacter cloacae, Shewanella putrefaciens MR-1, Desulfovibrio vulgaris, Geobacter metallireducens, Microbacterium sp. MP30. Sulfate-reducing bacteria provide $\mathrm{H}_{2} \mathrm{~S}$ for anaerobic chromate reduction. In an anaerobic culture medium, acetate, formate, fumarate and casamino acids can serve as electron donors ${ }^{[79-80]}$.

\section{Significance of ChrRs in chromium bioremediation}

A large number of industries are being incorporated in the urban as well as rural areas due to the rapidly growing industrialization in a global level. Apart from the benefits of the industrial sector, it has been a tremendous environmental concern regarding the pollution levels of wastewaters discharged from the industrial effluents. Metal-contamination is a serious threat due to the several applications of metals in tannery, textile, chemical, electrochemical, nuclear, alloy manufacture, and jewellery-making etc. Conventional methods to reduce toxic metal pollutants are chemical precipitation, oxidation and reduction, ion-exchange, filtration, membrane separation, evaporation and adsorption ${ }^{[81]}$ requiring high energy consumption and cumbersome techniques and cost-intensive equipments. Toxic sludge formation is also a disadvantage of conventional methods in terms of its disposal.

Bioremediation is a 'green' approach to conventional metal removal utilizing the metabolic processes of microorganisms to tolerate, increase resistance, detoxify and enzymatic reduction and other mechanisms to eliminate the metal pollution which can be in situ or ex situ directly at the contaminated site or at the treatment process facility through transportation ${ }^{[82-83]}$. Bioremediation of $\mathrm{Cr}$ by microorganisms is a viable and environmental-friendly approach for partial or complete metal toxicity abatement of the pollution load. $\mathrm{Cr}^{3+}$ is relatively benign than $\mathrm{Cr}^{6+}$ and insoluble which can therefore be removed by precipitation and processed for metal recovery. Though several procedures exist for toxic $\mathrm{Cr}^{6+}$ removal, enzyme-mediated biotransformation of toxic $\mathrm{Cr}^{6+}$ to non-toxic $\mathrm{Cr}^{3+}$ by microbial sources is a low-cost and efficient method for bioremediation of Cr-contaminated effluents and soils. This enzymatic reduction or chromate reduction to $\mathrm{Cr}^{3+}$ is mediated by a chromate reductase $(\mathrm{ChrR})$ which may be expressed in the soluble fraction or membrane-bound or extracellular in the culture supernatant.

A unique ChrR enzyme from Proteus sp. has been produced by optimized parameters and has been identified to have promising potential applications in the bioremediation of $\mathrm{Cr}$ as an ecofriendly and cost-effective approach ${ }^{[61]}$. Bhattacharya et al. ${ }^{[84]}$ have identified significant factors that affect the process of $\mathrm{Cr}$ bioremediation. These factors include: $\mathrm{pH}$ of the culture medium, temperature, initial $\mathrm{Cr}$ concentration, inoculum size, agitation speed, presence of electron donors and cocontaminants. Fernandez et al. ${ }^{[55]}$ have reviewed several bioremediation strategies at large-scale at the pilot level for $\mathrm{Cr}^{6+}$ removal for sustainable, environmental-friendly technology. Ma et al. ${ }^{[30]}$ have studied $\mathrm{Cr}$ bioremediation using a mixed bacterial consortium and have discussed the limited information of $\mathrm{ChrR}$ binding sites with $\mathrm{Cr}^{6+}$ among bacteria. Bacterial species reduce $\mathrm{Cr}^{6+}$ by enzymatic as well as non-enzymatic processes. ChrR-mediated chromate reduction can take place aerobically or anaerobically or via both. While aerobic reduction is mediated by soluble reductases, anaerobic chromate reduction is mediated by membrane-bound reductases ${ }^{[19]}$.

\section{Conclusion}

Although ChrRs are of considerable interests in the recent decades, there are yet a lot of studies to be undertaken for isolation and identification of potential chromate-reducing microorganisms and to understand their molecular mechanisms for bioremediation of metal polluted industrial wastewaters. Therefore, current attention should be towards enzymemediated (ChrR) chromate reduction for an economically viable and environmentally friendly pollution abatement particularly at pilot levels and high-capacity reactor levels for commercial exploitation. 


\section{Acknowledgements}

The authors thank Mr.Kikuji Takeuchi and Mr.Naomi Takeuchi of TAKENEN, Japan for their kind support and for the financial assistance to Dr. J.Geraldine Sandana Mala. Dr U. Mani and Mrs. D. Sujatha thank the Director, CSIR-CLRI, for his kind support.

\section{References}

[1] Bai RS, Abraham TE. Biosorption of chromium (VI) from aqueous solution by Rhizopus nigricans. Bioresource Technology. 2001; 79: 73-81.

[2] Dartsch PC, Kimmel R, Schmahl FW, et al. Nephrotoxic and hepatotoxic effects of a chromium (VI) compound in comparison to a basic chromium (III) tanning agent. World Leather. 1998; 11: 66-70.

[3] Baig MA, Mir M, Murtaza S, Bhatti ZI. Laboratory scale studies on removal of chromium from industrial wastes. Journal of Environmental Science (China). 2003; 15: 417-422.

[4] Zahoor A, Rehman A. Isolation of $\mathrm{Cr}(\mathrm{VI})$ reducing bacteria and industrial effluents and their potential use in bioremediation of chromium containing waste water. Journal of Environmental Science. 2009; 21: 814-820.

[5] Mala JGS, Nair BU, Puvanakrishnan R. Bioaccumulation and Biosorption of chromium by Aspergillus niger MTCC 2594. Journal of General and Applied Microbiology. 2006; 52: 179-186.

[6] Nepple BB, Kessi J, Bachofen R. Chromate reduction by Rhodobacter sphaeroides. Journal of Industrial Microbiology and Biotechnology. 2000; 25: 198-203.

[7] Abdel-Ghany TM, Alawlaqi MM, Shater ARM, et al. Congo red biosorption with live and dead biomass of thermophilic Aspergillus fumigatus. Egyptian Journal of Experimental Biology (Botany). 2019; 15: 1-6.

[8] Ganash MA, Abdel Ghany TM, Reyad AM. Pleurotus ostreatus as a biodegradator for organophosphorus insecticide Malathion. Journal of Environmental and Analytical Toxicology. 2016; 6: 369. doi:10.4172/2161-0525.1000369.

[9] Abdel Ghany TM, Al Abboud MA. Capacity of growing, live and dead fungal biomass for safranin dye decolourization and their impact on fungal metabolites. Australian Journal of Basic and Applied Sciences. 2014; 8: 489-499.

[10] Cervantes C, Campoc-Garcia J, Devars S. Interactions of chromium with microorganisms and plants. FEMS Microbiology Reviews. 2001; 25: 335-347.

[11] Elangovan R, Abipsa S, Rohit B, et al. Reduction of Cr(VI) by a Bacillus sp. Biotechnology Letters. 2006; 28: 247252.

[12] Camargo FA, Bento FM, Okeke BC, et al. Hexavalent chromium reduction by an Actinomycete, Arthrobacter acrytallopoietes ES 32. Biological Trace Element Research. 2004; 97: 183-194.

[13] Sanjay MS, Sudarsanam D, Raj GA, et al. Isolation and identification of chromium reducing bacteria from tannery effluent. Journal of King Saud University-Science. 2020; 32: 265-271.

[14] Barak Y, Ackerley DF, Dodge CJ, et al. Analysis of novel soluble chromate and uranyl reductases and generation of an improved enzyme by directed evolution. Applied and Environmental Microbiology. 2006; 72: 7074-7082.

[15] Robins KJ, Hooks DO, Rehm BHA, et al.. Escherichia coli NemA is an efficient chromate reductase that can be biologically immobilized to provide a cell-free system for remediation of hexavalent chromium. PLOS ONE. 2013; 8:e59200. doi:10.1371/journal.pone.0059200.

[16] Irazusta V, Bernal AR, Estevez MC, et al. Proteomic and enzyme response under $\mathrm{Cr}(\mathrm{VI})$ overload in yeast isolated from textile-dye industry effluent. Ecotoxicology and Environmental Safety. 2018; 148: 490-500.

[17] Zheng Z, Li Y, Zhang X, et al. A Bacillus subtilis strain can reduce hexavalent chromium to trivalent and nfrA gene is involved. International Biodeterioration and Biodegradation. 2015; 97: 90-96.

[18] Mala JGS, Sujatha D, Rose C. Inducible chromate reductase exhibiting extracellular activity in Bacillus methylotrophicus for chromium bioremediation. Microbiological Research. 2015; 170: 235-241.

[19] Thatoi H, Pradhan SK. Detoxification and bioremediation of hexavalent chromium using microbes and their genes: An insight into genomic, proteomic and bioinformatics studies. In: Microbial Biotechnology. 2017; 287-306.

[20] Ackerley DF, Gonzalez CF, Park CH, et al. Chromate-reducing properties of soluble flavoproteins from Pseudomonas putida and Escherichia coli. Applied and Environmental Microbiology. 2004; 70: 873-882.

[21] Cheung KH, Gu JD. Chromate reduction by Bacillus megatarium TKW3 isolated from marine sediments. World Journal of Microbiology and Biotechnology. 2005; 21: 213-219.

[22] Cheng G, Li X. Bioreduction of chromium by Bacillus sp. isolated from soils of iron mineral area. European Journal of Soil Biology. 2009; 45: 483-487.

[23] Ibrahim ASS, El-Tayeb MA, Elbadawi YB, et al. Bioreduction of $\mathrm{Cr}(\mathrm{VI})$ by potent novel chromate resistant 
alkaliphilic Bacillus sp. strain KSUCr5 isolated from hypersaline soda lakes. African Journal of Biotechnology. 2011; 10: 7207-7218.

[24] Mangaiyarkarasi MSM, Vincent S, Janarthanan S, et al. Bioreduction of Cr(VI) by alkaliphilic Bacillus subtilis and interaction of the membrane groups. Saudi Journal of Biological Sciences. 2011; 18: 157-167.

[25] Chaturvedi MK. Studies on chromate removal by chromium-resistant Bacillus sp. isolated from tannery effluent. Journal of Environmental Protection. 2011; 2: 76-82.

[26] Chen Z, Huang Z, Cheng Y, et al. Cr(VI) uptake mechanism of Bacillus cereus. Chemosphere. 2012; 87: 211-216.

[27] Ontanon OM, Fernandez M, Agostini E, et al. Identification of the main mechanisms involved in the tolerance and bioremediation of Cr(VI) by Bacillus sp. SFC 500-1E. Environmental Science and Pollution Research International. 2018; 25: 16111-16120.

[28] Li M, He Z, Hu Y, et al. Both cell envelope and cytoplasm were the locations for chromium (VI) reduction by Bacillus sp. M6. Bioresource Technology. 2019; 273: 130-135.

[29] Cheung KH, Gu J. Mechanism of hexavalent chromium detoxification by microorganisms and bioremediation potential: A review. International Biodeterioration and Biodegradation. 2007; 59: 8-15.

[30] $\mathrm{Ma} \mathrm{L}, \mathrm{Xu}$ J, Chen N. Microbial reduction fate of chromium $(\mathrm{Cr})$ in aqueous solution by mixed bacterial consortium. Ecotoxicology and Environmental Safety. 2019; 170: 763-770.

[31] Rath BP, Das S, Mohapatra PKD, et al. Optimization of extracellular chromate reductase production by Bacillus amyloliquefaciens (CSB 9) isolated from chromite mine environment. Biocatalysis and Agricultural Biotechnology. 2014; $3: 35-41$.

[32] Dey S, Paul AK. Evaluation of chromate reductase activity in the cell-free culture filtrate of Arthrobacter sp. SUK 1201 isolated from chromite mine overburden. Chemosphere. 2016; 156: 69-75.

[33] Prabha AS, Prabakaran V. The role of chromate reductase enzyme activity for effective reduction of chromium by Pseudomonas aeruginosa. International Journal of Current Medical and Pharmaceutical Research. 2017; 3: 25952600.

[34] Elahi A, Rehman A. Oxidative stress, chromium-resistance and uptake by fungi: Isolated from industrial wastewater. Brazilian Archives of Biology and Technology. 2017; 60: 1-14.

[35] Ray RR, Sur D, Kundu A. Preliminary characterization of a NADPH dependent chromate reductase from Trichoderma pseudokoningii. Journal of Microbiology and Microbial Technology. 2016; 1: 1-4.

[36] Sallau AB, Inuwa HM, Ibrahim S, et al. Isolation and properties of chromate reductase from Aspergillus niger. International. Journal of Modern Cellular and Molecular Biology. 2014; 3: 10-21.

[37] Arevalo-Rangel D, Cardenas-Gonzalez JF, Martinez-Judrez VM, et al. Hexavalent chromate reductase activity in cellfree extracts of Pencillium sp. Bioinorganic Chemistry and Applications. 2013; 1-6.

[38] Gu Y, Xu W, Liu Y, et al. Mechanism of Cr(VI) reduction by Aspergillus niger: enzymatic characteristic, oxidative stress response, and reduction product. Environmental Science and Pollution Research International. 2015; 22: 62716279.

[39] Ancona V, Campanale C, Tumolo M, et al. Enhancement of chromium (VI) reduction in microcosms amended with lactate or yeast extract: A laboratory-scale study. International Journal of Environmental Research and Public Health. 2020; 17: 704. doi:10.3390/ijerph17030704.

[40] Mohamed MSM, El-Arabi NI, El-Hussein A, et al. Reduction of chromium-VI by chromium-resistant Escherichia coli FACU: a prospective bacterium for bioremediation. Folia Microbiologica. 2020; doi.org/10.1007/s12223-02000771-y.

[41] Desai C, Jain K, Madamwar D. Hexavalent chromate reductase activity in cytosolic fractions of Pseudomonas sp. G1DM21 isolated from Cr(VI) contaminated industrial landfill. Process Biochemistry. 2008; 43: 713-721.

[42] Baldiris R, Acosta-Tapia N, Montes A, et al. Reduction of hexavalent chromium and detection of chromate reductase (ChrR) in Stenotrophomonas maltophilia. Molecules. 2018; 23: 1-20.

[43] Polti MA, Amoroso MJ, Abate CM. Chromate reductase activity in Streptomyces sp. MC1. Journal of General and Applied Microbiology. 2010; 56: 11-18.

[44] Wani PA, Wani JA, Wahid S. Recent advances in the mechanism of detoxification of genotoxic and cytotoxic Cr(VI) by microbes. Journal of Environmental Chemical Engineering. 2018; 6: 3798-3807.

[45] Algamdi AY, Alharbi SA, Wainwright M, et al. Role of the enzyme chromate reductase in detoxification of potassium dichromate $\left(\mathrm{Cr}^{+6}\right)$ by bacteria. International Journal of Agronomy and Agricultural Research. 2017; 11: 63-69.

[46] Zeng Q, Hu Y, Yang Y, et al. Cell envelop is the key site for Cr(VI) reduction by Oceanobacillus oncorhynchi W4, a newly isolated $\mathrm{Cr}(\mathrm{VI})$ reducing bacterium. Journal of Hazardous Materials. 2019; 368: 149-155.

[47] Opperman DJ, Piater LA, van Heerden E. A novel chromate reductase from Thermus scotoductus SA-01 related to old yellow enzyme. Journal of Bacteriology. 2008; 190: 3076-3082.

[48] Jin H, Zhang Y, Buchko GW, et al. Structure determination and functional analysis of a chromate reductase from 
Gluconacetobacter hansenii. PLOS One. 2012; 7: e42432.

[49] Zou L, Liu P, Li X. New advances in molecular mechanism of microbial hexavalent chromium reduction. International Journal of Biotechnology and Food Science. 2013; 1: 46-55.

[50] Eswaramoorthy S, Poulain S, Hienerwadal R, et al. Crystal structure of ChrR-a quinone reductase with the capacity to reduce chromate. PLOS One. 2012; 7: e36017.

[51] Khaleel JA, Gong C, Zhang Y, et al. Mutations in FMN binding pocket diminish chromate reduction rates for GhChrR isolated from Gluconacetobacter hansenii. Natural Science. 2013; 5: 20-24.

[52] Brown SD, Thompson MR, VerBerkmoes NC, et al. Molecular dynamics of the Shewanella oneidensis response to chromate stress. Molecular and Cellular Proteomics. 2006; 5: 1054-1071.

[53] Bhattacharya P, Barnebey A, Zemla M, et al. Complete genome sequence of the chromate-reducing bacterium Thermoanaerobacter thermohydrosulfuricus strain BSB-33. Standards in Genomic Sciences. 2015; 10: 74.

[54] Zhou S, Dong L, Deng P, et al. Reducing capacity and enzyme activity of chromate reductase in a ChrT-engineered strain. Experimental and Therapeutic Medicine. 2017; 14: 2361-2366.

[55] Deng P, TanX, Wu Y, et al. Cloning and sequence analysis demonstrate the chromate reduction ability of a novel chromate reductase gene from Serratia sp. Experimental and Therapeutic Medicine. 2015; 9: 795-800.

[56] Patra RC, Malik S, Beer M, et al. Molecular characterization of chromium (VI) reducing potential in Gram positive bacteria isolated from contamination sites. Soil Biology and Biochemistry. 2010; 42: 1857-1863.

[57] Pei QH, Shahir S, Sandhana Raj AS, et al. Chromium (VI) resistance and removal by Acinetobacter haemolyticus. World Journal of Microbiology and Biotechnology. 2009; 25: 1085-1093.

[58] Gonzalez CF, Ackerley DF, Lynch SV, et al. ChrR a soluble quinone reductase of Pseudomonas putida that defends against $\mathrm{H}_{2} \mathrm{O}_{2}$. Journal of Biological Chemistry. 2005; 280: 22590-22595.

[59] Suzuki T, Miyata N, Horitsu H, et al. NAD(P)H-dependent chromium (VI) reductase of Pseudomonas ambigua G-1: a $\mathrm{Cr}(\mathrm{V})$ intermediate is formed during the reduction of $\mathrm{Cr}(\mathrm{VI})$ to $\mathrm{Cr}(\mathrm{III})$. Journal of Bacteriology. 1992; 174: 53405346.

[60] Rao P, Sarkar PS, Kaiwar SP, et al. Chromate reductase activity: characterization of $\mathrm{Cr}(\mathrm{VI})$ to $\mathrm{Cr}(\mathrm{III})$ conversion. Proceedings of Indian Academy of Sciences (Chemical Sciences). 1990; 102: 219-230.

[61] Jhunjhunwala P, Roy R, Roy S, et al. Bioremediation of chromium by unique chromium reductase activity in Proteus sp. isolated from wastewater. International Journal of Applied Research. 2016; 2: 249-256.

[62] Banerjee S, Kamila B, Barman S, et al. Interlining Cr(VI) remediation mechanism by a novel bacterium Pseudomonas brenneri isolated from coalmine wastewater. Journal of Environmental Management. 2019; 233: 271-282.

[63] He Y, Gong Y, Su Y, et al. Bioremediation of $\mathrm{Cr}(\mathrm{VI})$ contaminated groundwater by Geobacter sulfurreducens: Environmental factors and electron transfer flow studies. Chemosphere. 2019; 221: 793-801.

[64] Focardi S, Pepi M, Focardi SE. Microbial reduction of hexavalent chromium as a mechanism of detoxification and possible bioremediation applications. Chamy R, Rosenkranz F (Eds.) In: Biodegradation-Life of Science. 2013; 321347.

[65] Garbisu C, Alkorta I, Llama MJ, et al. Aerobic chromate reduction by Bacillus subtilis. Biodegradation. 1998; 92 : $133-141$.

[66] Myers CR, Carstens BP, Antholin WE, et al. Chromium(VI) reductase activity is associated with the cytoplasmic membrane of anaerobically grown Shewanella putrefaciens MR-1. Journal of Applied Microbiology. 2000; 88, 98106.

[67] Xu L, Luo M, Li W, et al. Reduction of hexavalent chromium by Pannonibacter phragmitetus LSSE-09 stimulated with external electron donors under alkaline conditions. Journal of Hazardous Materials. 2011; 185, 1169-1176.

[68] Laxman RS, More S. Reduction of hexavalent chromium by Streptomyces griseus. Minerals Engineering. 2002, 15: 831-833.

[69] Germain LE, Patterson KE. Plating and cyanide wastes. Journal of the Water Pollution Control Federation. 46: 13011315.

[70] Wang YT, Shen, H. Bacterial reduction of hexavalent chromium: A review Journal of Industrial Microbiology. 1995; 14: $159-163$.

[71] Shen H, Wang YT. Characterization of enzymatic reduction of hexavalent chromium by Escherichia coli ATCC 33456. Applied Environmental Microbiology. 1993; 59: 3771-3777.

[72] Bopp LH, Ehrlich HL. Chromate resistance and reduction in Pseudomonas fluorescens strain LB300. Archives of Microbiology. 1988; 150: 426-431.

[73] Narayani M, Vidya Shetty K. Chromium-resistant bacteria and their environmental condition for hexavalent chromium removal: A Review. Critical Reviews in Environmental Science and Technology. 2013; 43: 955-1009, doi: 10.1080/10643389.2011.627022.

[74] Puzon GJ, Petersen JN, Roberts AG, et al. A bacterial flavin reductase system reduces chromate to a soluble chromium 
(III)-NAD+ complex. Biochemical and Biophysical Research Communications. 2002, 294: 76-81.

[75] Thatoi H, Das S, Mishra J, et al. Bacterial chromate reductase, a potential enzyme for bioremediation of hexavalent chromium: A review. Journal of Environmental Management. 2014; 146: 383-399.

[76] McLean J, Beveridge TJ. Chromate reduction by a pseudomonad isolated from a site contaminated with chromated copper arsenate. Applied Environmental Microbiology. 2001; 67: 1076-1084.

[77] Romaneka VI, Korenkov VN. Bacterial reduction of ions. Inform. Byul. In-ta. Biol.Vnutr. Vod.Akad, Nauk SSR. 1975; 25, 8.

[78] Singh R, Kumar A, Kirrolia A, et al. Removal of sulfate, COD and Cr(VI) in simulated and real wastewater by sulfate reducing bacteria enrichment in small bioreactor and FTIR study. Bioresource Technology. 2011: 102: 677-682.

[79] Viamajala S, Peyton BM, Sani RK, et al. Toxic effects of Chromium (VI) on anaerobic and aerobic growth of Shewanella oneidensis MR-1. Biotechnology Progress. 2004; 20: 87-95.

[80] Wang PC, Mori T, Komori K, et al. Isolation and characterization of an Enterobacter cloacae strain that reduces hexavalent chromium under anaerobic conditions. Applied Environmental Microbiology. 1989; 55: 1665-1669.

[81] Barceloux DG, Barceloux D. Chromium. Clinical Toxicology. 1999; 37, 173-194.

[82] Abdel-Razek AS, Abdel-Ghany TM, Mahmoud SA, et al. Treatment of liquid hazardous wastes by using the fungus Cunninghamella elegans. Journal of Radiation Research and Applied Sciences. 2009a; 2: 890-902.

[83] Abdel-Razek AS, Abdel-Ghany TM, Mahmoud SA, et al. The use of free and immobilized Cunninghamella elegans for removing cobalt ions from aqueous waste solutions. World Journal of Microbiology and Biotechnology. 2009b; doi: 10.1007/s11274-009-0118-Z

[84] Bhattacharya A, Gupta A, Kaur A, et al. Alleviation of hexavalent chromium by using microorganisms: Insight into the strategies and complications. Water Science and Technology. 2019; 79: 411-424.

[85] Fernandez PM, Vinarta SC, Bernal AR, et al. Bioremediation strategies for chromium removal: Current research, scale-up approach and future perspectives. Chemosphere. 2018; 208: 139-148. 